\title{
Cavitand Zn(II)-Porphyrin Capsules with High Affinities for Pyridines and N-Methylimidazole
}

\author{
Oskar Middel, Willem Verboom,* and David N. Reinhoudt* \\ Laboratory of Supramol ecular Chemistry and Technology, MESA ${ }^{+}$Research Institute, \\ University of Twente, P.O. Box 217, NL-7500 AE Enschede, The Netherlands \\ smct@ct.utwente.nl
}

Received J anuary 26, 2001

\begin{abstract}
Covalent cavitand $\mathrm{Zn}(\mathrm{II})$ - porphyrins 17-20 were prepared via multistep syntheses. These host molecules show moderate to excellent binding affinities to $\mathrm{N}$-methylimidazole and pyridine guests. The complexing behavior strongly depends on the spacer's length, number, and rigi dity, in addition to the guest size. Cavitand capping and strapping of porphyrins strongly influence the complex formation and result in a 10-700-fold enhancement of the binding strength compared to tetraphenyl Zn(II)-porphyrin.
\end{abstract}

\section{Introduction}

Porphyrins are of biological importance and therefore widely used in supramolecular chemistry in order to mimic porphyrin-containing active sites of proteins and enzymes. ${ }^{1}$ Fenced, strapped, and a few capped porphyrins show that a hydrophobic pocket on top of the metalcontaining porphyrin platform enhances the coordination of electron-donating ligands to the metal center. ${ }^{2}$ The capability of the hydrophobic pocket of the capped, strapped, and fenced $\mathrm{Zn}(\mathrm{II})$-porphyrins to stabilize the axial binding of ligands is commonly studied by comparison with tetraphenylporphyrin(Zn) $(\operatorname{TPP}(Z n)){ }^{3}$

A number of porphyrin-containing receptors has been published in the literature during the past two decades. Different host molecules such as cyclodextrins, ${ }^{4}$ crown ethers, ${ }^{5}$ and calix[4]arenes ${ }^{6}$ have been used to bridge or cap a porphyrin. In addition to the $\mathrm{Zn}(\mathrm{II})$-porphyrin trimer reported by Sanders et al., ${ }^{7}$ there are a few $\mathrm{Zn}(\mathrm{II})$-porphyrin-containing receptors that bind axial guests in organic solvents with an association constant of $>10^{6} \mathrm{M}^{-1}$. The capped porphyrins reported by $\mathrm{N}$ olte et al. ${ }^{8}$ and Uemori et al. ${ }^{9}$ show binding of axial guests with an association constant up to $10^{7} \mathrm{M}^{-1}$ in $\mathrm{CDCl}_{3}$. As part of our work to build receptors via a combination of simple building blocks, ${ }^{10}$ we have reported a calix[4]arene doubly strapped porphyrin. ${ }^{6}$ The receptor binds N-het-

(1) (a) Lehn, J .-M. Science 1985, 227, 849. (b) Collman, J . P.; Zhang, X.; Lee, V. L.; Uffelman, E. S.; Brauman, J . I. Science 1993, 261, 1405.

(2) Feiters, M. C. In Comprehensive Supramolecular Chemistry: Atwood, J . L., Davies, J . E. D., MacNicol, D. D., Vögtle, F., Reinhoudt, D. N., Lehn, J .-M., Eds.; Elsevier Science Ltd.' Pergamon: Elmsford, 1996; Vol. 10, pp 267-360.

(3) Stryer, L. Biochemistry, 3rd ed.; W. H. Freeman and Co.: New York, 1988; Chapter 7.

(4) Kuroda, Y.; I to, M.; Sera, T.; Ogoshi, H. J . Am. Chem. Soc. 1993 $115,7003$.

(5) Gunter, M. J .; J eynes, T. P.; J ohnston, M. R.; Turner, P.; Chen, Z. J. Chem. Soc., Perkin Trans. 1 1998, 1945.

(6) Rudkevich, D. M.; Verboom, W.; Reinhoudt, D. N.J . Org. Chem. 1995, 60, 6585

(7) Vidal-Ferran, A.; Müller, C. M.; Sanders, J . K. M. J . Chem. Soc., Chem. Commun. 1994, 2657.

(8) Elemans, J . A. A. W.; Claase, M. B.; Aarts, P. P. M.; Rowan, A. E.; Schenning, A. P. H. J .; Nolte, R. J . M. J . Org. Chem. 1999, 64, 7009.

(9) Imai, H.; Munakata, H.; Takahashi, A.; Nakagawa, S.; I hara, Y.; Uemori, Y.j . Chem. Soc., Perkin Trans. 2 1999, 2565. erocycles approximately $10-10^{3}$ times stronger than unsubstituted porphyrins, reflecting the shielding effect of the calix[4]arene moieties; for picoline and N-methylimidazole $\mathrm{K}$ values $>10^{6} \mathrm{M}^{-1}$ in $\mathrm{CDCl}_{3}$ were found. In the literature a few other calix[4]arene-porphyrin assemblies are known. A calix[4]arene was used to cap an $\mathrm{Fe}(\mathrm{III})$ - porphyrin resulting in an excellent oxygen carrier in membranes ${ }^{11}$ and a calix[4]arene was coupled to a porphyrin using the porphyrin as a fluorescent probe for monitoring the binding of organic guests in the calix[4]arene. ${ }^{12}$

A cavitand has a completely rigidified and defined cavity, and a strong enhancement of the binding properties of the $\mathrm{Zn}(\mathrm{II})$-porphyrin is therefore expected when the cavitand functions as a porphyrin cap. This paper describes the first cavitand-capped and -strapped porphyrins together with a systematic study on the shielding effect of the cavitand related to the number, flexibility, and length of the spacers. This is expressed in a very strong enhancement of the binding of $\mathrm{N}$-methylimidazole and pyridine guests compared to the binding to TPP(Zn).

\section{Results and Discussion}

Synthesis. The capped and strapped porphyrins were synthesized starting from cavitand tetraamine $\mathbf{1}^{13}$ and diamine 2,14 respectively (Scheme 1 ). Reaction of the amines with either chloroacetyl chloride or 6-bromohexanoic acid chloride gave the corresponding di- $(3,4)$ and tetraamides $(\mathbf{5}, \mathbf{6})$ in excellent yields $(>93 \%)$, whereupon the corresponding aldehydes $\mathbf{7 - 1 0}$ were prepared via a Williamson ether synthesis by reacting amides 3-6 with salicylal dehyde. The dialdehydes $\mathbf{7}$ and $\mathbf{8}$ were converted to the corresponding bis(di-2-pyrrolylmethyl) precursors $\mathbf{1 1}$ and $\mathbf{1 2}$ by adding $10 \mathrm{~mol} \%$ of trifluoroacetic acid to a solution of $\mathbf{7}$ and $\mathbf{8}$ in pyrrole, respectively.

(10) Higler, I.; Timmerman, P.; Verboom, W.; Reinhoudt, D. N. Eur J. Org. Chem. 1998, 2689.

(11) Kobayashi, N.; Mizuno, K.; Osa, T. Inorg. Chim. Acta 1994, 224, 1.

(12) Milbrandt, R.; Weiss, J . Tetrahedron Lett. 1995, 36, 2999.

(13) Boerrigter, H.; Verboom, W.; Reinhoudt, D. N. J . Org. Chem. 1997, 62, 7148.

(14) Boerrigter, H.; Verboom, W.; Van Hummel, G. J .; Harkema, S.; Reinhoudt, D. N. Tetrahedron Lett. 1996, 37, 5167. 
Scheme 1<smiles>CCOc1c(C2CC3CCC2C3)cc2c(c1CN)OCC2</smiles>

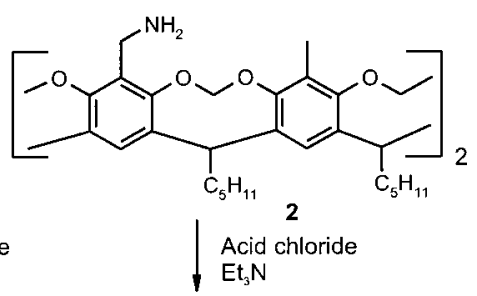<smiles>NC(=O)NCc1c(C2CC3CC(C2)C3O)cc2c(c1OCC(=O)O)OC2</smiles>

$5 \mathrm{R}=\mathrm{CH}_{2} \mathrm{Cl}$ $6 \mathrm{R}=\left(\mathrm{CH}_{2}\right)_{5} \mathrm{Br}$

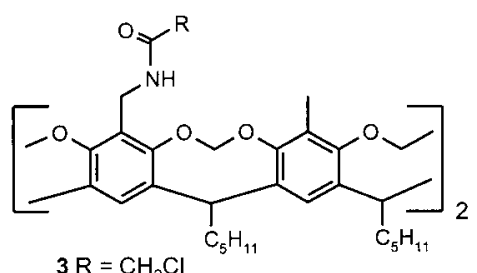
$3 \mathrm{R}=\mathrm{CH}_{2} \mathrm{Cl}$ $4 \mathrm{R}=\left(\mathrm{CH}_{2}\right)_{5} \mathrm{Br}$<smiles>CCOc1c(C2CC3CCC2C3)cc2c(c1CNC(=O)COc1ccccc1C)OCC2</smiles>
$9 n=1$ $10 n=5$

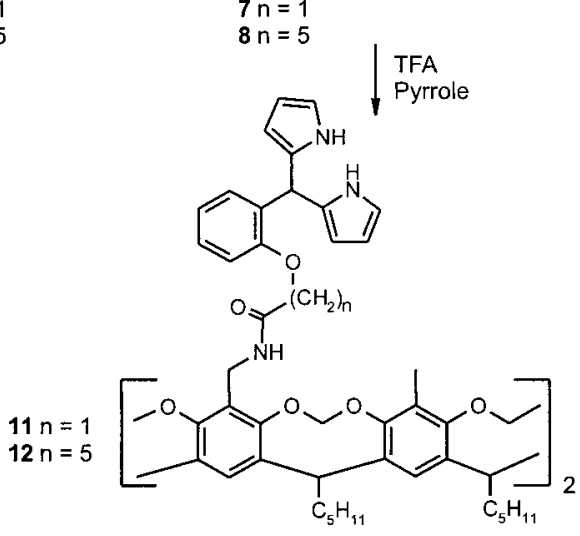

The conversi on of tetraaldehydes $\mathbf{9}$ and $\mathbf{1 0}$ and dipyrromethanes 11 and $\mathbf{1 2}$ to capped porphyrins 13 and 14 and strapped porphyrins $\mathbf{1 5}$ and $\mathbf{1 6}$ was accomplished in yields comparable to those of other systems reported and proved to be strongly dependent on the synthetic methods applied. The conversion of $\mathbf{9}$ to capped porphyrin 13 could only be accomplished by using the Adler conditions; ${ }^{15}$ other methods showed no porphyrin formation. Only when applying the Lindsey equilibrium conditions, ${ }^{16}$ using $\mathrm{BF}_{3}$ as the catalyst, could capped porphyrin 14 be obtained. The best results for strapped porphyrins 15 and 16 were obtained via the Lindsey method ${ }^{16}$ via TFA and $\mathrm{BF}_{3}$ catalysis, respectively (Chart 1$) .{ }^{17}$

(15) Adler, A. D.; Longo, F. R.; Finarelli, J . D.; Goldmacher, J .; Assour, J .; Korsakoff, L. J . Org. Chem. 1967, 32, 476.

(16) Lindsey, J. S.; Schreiman, I. C.; Hsu, H. C.; Kearney, P. C.; Marguerettaz, A. M. J . Org. Chem. 1987, 52, 827.

(17) We have chosen ball-and-stick model representations for the cavitand $\mathrm{Zn}(\mathrm{II})$ - porphyrins instead of, e.g., I sis-draw pictures for clarity.

\section{Chart 1}

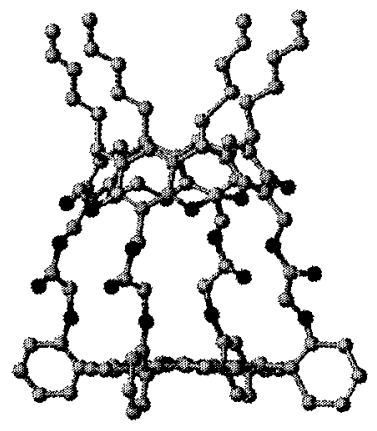

$13(2 H)$-porphyrin $17(\mathrm{Zn})$-porphyrin

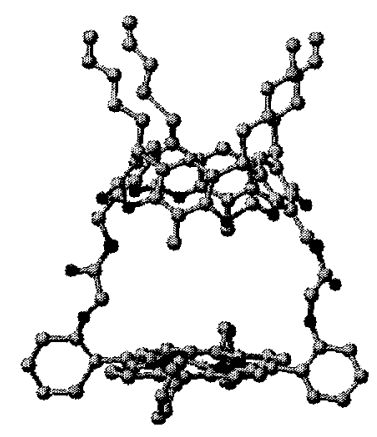

$15(2 H)$-porphyrin $19(\mathrm{Zn})$-porphyrin

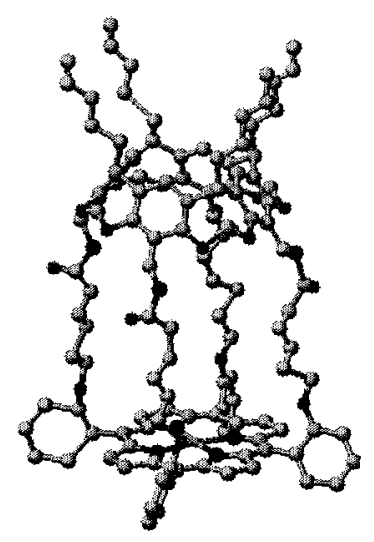

$14(2 H)$-porphyrin $18(\mathrm{Zn})$-porphyrin

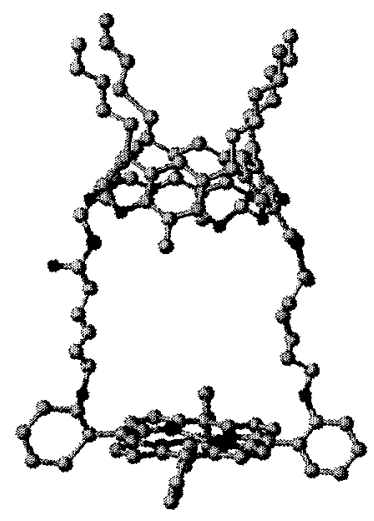

$16(2 H)$-porphyrin $20(\mathrm{Zn})$-porphyrin
The capped (2H)-porphyrins $\mathbf{1 3}-\mathbf{1 6}$ were easily identified by the signals of the porphyrin-core hydrogen atoms resonating around $\delta-2.8$ in the ${ }^{1} \mathrm{H}$ NMR spectra and by the molecular ion peak in the positive FAB mass spectra. They could not be obtained analytically pure after column chromatography due to their slight instability. Treatment of the capped $(2 \mathrm{H})$-porphyrins $\mathbf{1 3} \mathbf{- 1 6}$ with a large excess of $\mathrm{Zn}(\mathrm{OAC})_{2}$ afforded the stable cavitand $\mathrm{Zn}(\mathrm{II})$ - porphyrins 17-20 which could easily be purified by flash column chromatography. ${ }^{18}$ The overall yields for $\mathbf{1 7 - 2 0}$ of the last two reaction steps, the porphyrin syntheses and the subsequent insertion of the $\mathrm{Zn}(\mathrm{II})$ center, were $0.9 \%, 6 \%$, $3 \%$, and $5 \%$, respectively.

NMR Analysis. Structural proof for the cavitand Zn(II)-porphyrins 17-20 was obtained by several NMR techniques. The ${ }^{1} \mathrm{H}$ NMR spectrum of capped $\mathrm{Zn}(\mathrm{II})$-porphyrin 18 (Figure 1 ) clearly shows its C-4 symmetry. The assignment of the signals originating from the flexible pentylamido- $\mathrm{N}$-methylene spacers was accomplished by combining the COSY and TOCSY NMR spectra. The middle three methylene groups have shifted (about $1.0 \mathrm{ppm}$ ) to an upfield position due to the porphyrin's ring current; two of the methylene groups are resonating at around $\delta 0.7$, the other (closest to the porphyrin) at $\delta$ 0.9. The $\mathrm{OCH}_{2}$ methylene group is just outside the ring current since it is residing as a triplet at $\delta 3.74$.

The introduction of short amide-containing spacers rigidifies the cavitand-porphyrin system for $\mathbf{1 7}$ and $\mathbf{1 9}$.

(18) The purity of capped $\mathrm{Zn}(\mathrm{II})$ - porphyrin $\mathbf{1 8}$ follows from the ${ }^{1 \mathrm{H}}$ NMR spectrum (Figure 1). 


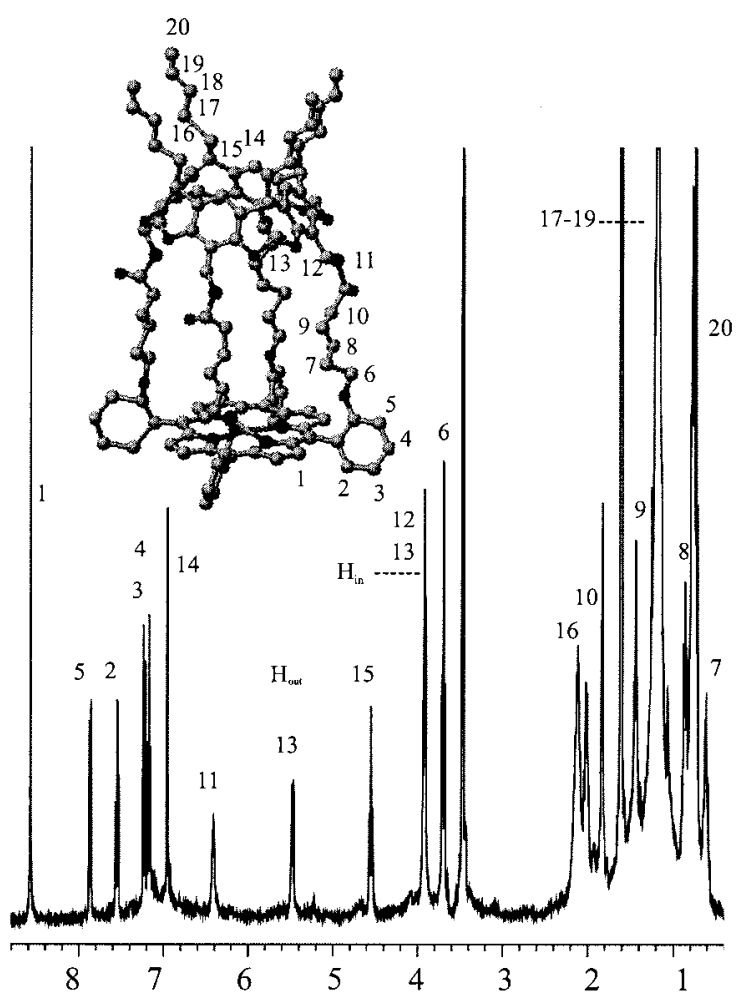

Figure 1. ${ }^{1} \mathrm{H}$ NMR spectrum of $\mathbf{1 8}$ in $\mathrm{CDCl}_{3}$.

The distance between the cavitand cap and the porphyrin will be fixed and is contrasting the structural flexibility in 18. Slow rotation of the short linker groups results in an ${ }^{1} \mathrm{H}$ NMR spectrum consisting of broadened multiple signals for, e.g., the spacers and methylenedioxy bridges, ${ }^{19}$ and the expected $\mathrm{C}_{4}$ symmetry of $\mathbf{1 7}$ and the $\mathrm{C}_{2}$ symmetry of 19 is lost. COSY and NOESY spectra only show the expected contacts for the cavitand and porphyrin part of the molecule and in particular between the $\mathrm{H}_{\text {in }}$ and $\mathrm{H}_{\text {out }}$ multiplet regions for the hydrogen atoms of the methylenedioxy bridges and between the different multiplet regions residing from the hydrogen atoms of the spacer.

Strapped porphyrin 20 exhibits a complex ${ }^{1} \mathrm{H}$ NMR spectrum in $\mathrm{CD}_{2} \mathrm{Cl}_{2}$. The aryl substituents of the porphyrin reside as two multiplet regions between $\delta 7.4$ and 7.8. Furthermore, many of the signals are doubled or broadened. A clear contact in the ROESY NMR spectrum was found between the resonances of the $\mathrm{OCH}_{\text {in }} \mathrm{O}$ and the resonance of one hydrogen atom of one of the benzene substituents of the porphyrin. In addition, contacts between the phenyl group and three of the five methylene spacer groups could be observed. Flexibility of the spacers might enable the receptor to accommodate its cavity size to that of the guest. However, in strapped porphyrin $\mathbf{2 0}$ self-inclusion takes place by the association of one of the phenyl substituents of the porphyrin into the cavity of the cavitand when dissolved in $\mathrm{CD}_{2} \mathrm{Cl}_{2}$.

This self-inclusion process is solvent dependent as can be clearly seen in Figure 2. In the competitive solvent THF $-\mathrm{d}_{8}, 20,21$ the cavity is occupied by a solvent molecule resulting in a ${ }^{1} \mathrm{H}$ NMR spectrum with a $\mathrm{C}_{2}$-symmetry

(19) Different rotamers are formed. The carbonyl groups in the linkers can be positioned inward versus outward and combinations thereof.

(20) Solvent inclusion has been described by Cram: Cram, D. J . Science 1988, 240, 760.
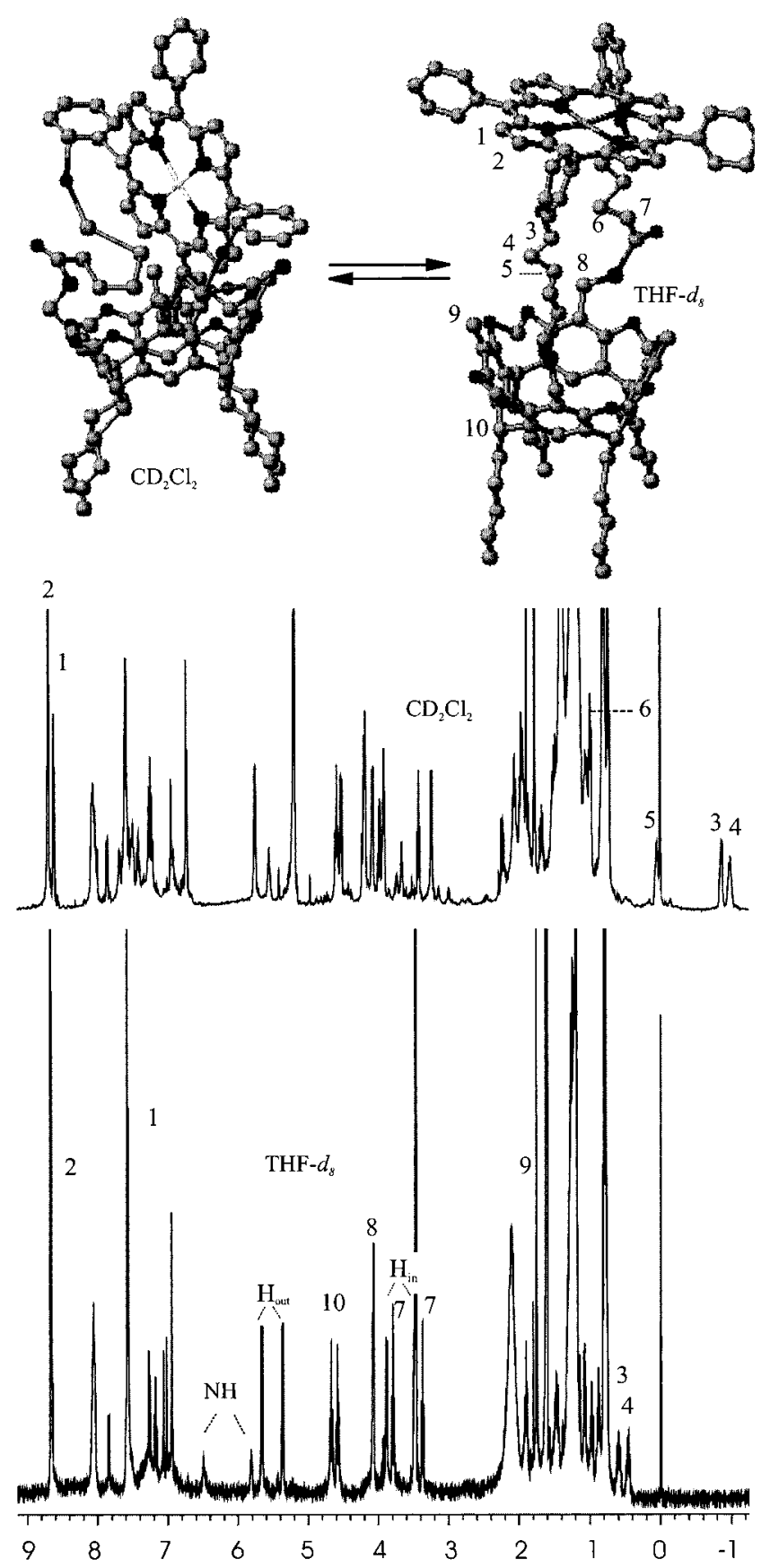

Figure 2. Self-inclusion of $\mathbf{2 0}$ illustrated by its ${ }^{1} \mathrm{H}$ NMR spectra in $\mathrm{CD}_{2} \mathrm{Cl}_{2}$ (top) and in THF-d (bottom).

expressed by the doubled set of signals for the amide, methine, and methylenedioxy bridges (Figure 2). The plane of symmetry can only be positioned where it is bisecting two distal methylenedioxy bridges. This is the case when, on average, the oxygen atom of the bound THF $-\mathrm{d}_{8}$ is pointing out of the cavity toward one of the amides. Although the amides have an equal distance to the plane of symmetry, they are therefore inequivalent, which is also reflected in the $\mathrm{Ar}-\mathrm{H}$ signals of the cavitand; one of the two expected signals is doubled giving three signals integrating in a 1:1:2 fashion.

(21) From other aminomethyl-substituted cavitands prepared in our laboratories, it is already known that, in $\mathrm{CDCl}_{3}, \mathrm{THF}$ is bound inside the cavity with an association constant of $\sim 500 \mathrm{M}^{-1}$. Unpublished results. 
Because of the ring current of the porphyrin, in $\mathrm{CD}_{2} \mathrm{Cl}_{2}$ the $\mathrm{CH}_{2}$ signals of the spacers are expected to resonate at an upfield position; ${ }^{22}$ due to the self-inclusion process, they have even shifted to negative $\delta$ values (Figure 2). In THF - $\mathrm{d}_{8}$ these resonances have shifted far downfield at positions where they are expected. The combination of TOCSY and COSY spectra was used to assign the signals of the methylene groups of the spacers of 20 in $\mathrm{CD}_{2} \mathrm{Cl}_{2}$. The $\mathrm{OCH}_{2}$ group $(\delta-0.91)$ has only one contact in the COSY spectrum with its neighboring methylene group $(\delta-0.96)$, which has two contacts. The other methylene substituents were assigned by TOCSY NMR spectroscopy and are located at $\delta 0.14,1.03$, and 3.79. ${ }^{23}$ Knowing the positions, the COSY spectrum re veals the position of the methylene groups in the spacer. The methylene group next to the amide is residing at $\delta$ 3.79 , and it has a contact with its neighboring methylene group located at $\delta$ 1.03. Consequently, the middle methylene group is located at $\delta 0.14$.

Illustrative also are the changes in the splitting patterns for the two different hydrogen atoms of the pyrrole moieties of the porphyrin part of the receptor when going from $\mathrm{CD}_{2} \mathrm{Cl}_{2}$ to THF-d $\mathrm{d}_{8}$. Because of the folding of the molecule in $\mathrm{CD}_{2} \mathrm{Cl}_{2}$, these two signals, and many others, split up into multiple signals (Figure 2). In the THF $-\mathrm{d}_{8}$ comple ${ }^{21}$ they become two signals which reside as a broad singlet at $\delta 8.06$ and as a multiplet at around $\delta 8.67$. The phenyl substituents now exhibit one narrow multiplet. ${ }^{24}$

UV-Binding Experiments. The complexation be havior of the cavitand $\mathrm{Zn}(\mathrm{II})$-porphyrin receptors 17-20 toward $\mathrm{N}$-methylimidazole and a series of pyridine guests in $\mathrm{CHCl}_{3}$ was studied by UVtitrations. As an illustration, Figure 3 shows the Soret band for cavitandcapped $\mathrm{Zn}(\mathrm{II})$-porphyrin $\mathbf{1 7}$ and of the complex in $\mathrm{CHCl}_{3}$ upon picoline addition. Both the decrease of the Soret absorbance band of the free host at $\lambda=424 \mathrm{~nm}$ and the increase of the Soret absorbance band of the complex at $\lambda=434 \mathrm{~nm}$ are plotted as a function of the guest concentration. Both curves gave, after correction for dilution, a perfect fit to a 1:1 model $\left(K_{\text {ass }}=2.3 \times 10^{5} \mathrm{M}^{-1}\right)$. The UV titration spectra, when corrected for dilution, show the typical isosbestic point between the maximum absorbance of the free host and that of the complex.

The results of the binding studies are summarized in Table $1 .{ }^{25} \mathrm{~F}$ or a few cases, the binding affinities of the cavitand $\mathrm{Zn}(\mathrm{II})$ - porphyrins are in the same range (about $10^{6} \mathrm{M}^{-1}$ ) as those of the the best known receptors for organic guests in organic solvents to date, ${ }^{6-9}$ demonstrating the strong potential of a cavitand as a hydrophobic pocket. Some important trends can be seen from the results. The strongest axial binding of $\mathrm{N}$-methylimidazole

(22) Momenteau, M.; Mispelter, J .; Loock, B.; Bisagni, E. J . Chem. Soc., Perkin Trans. 2 1983, 189.

(23) Many contacts are observed for the alkyl region in the COSY NMR spectrum. TOCSY NMR shows the expected four contacts for all spacer methylene groups in a straight line.

(24) When the sample was measured at $223 \mathrm{~K}$, the hydrogens of the porphyrin-pyrrole units appear as two doublets between $\delta 8.1$ and 8.2 and as two doublets between $\delta 8.6$ and 8.7. In addition, the doublet originating from the methylene group between the amide and the cavitand is doubled at $223 \mathrm{~K}$, which clearly indicates the difference in spatial freedom between both amide moieties in time and the symmetry elements being lost.

(25) Pyridine, picoline, and N-methylimidazole are common guests for studying the binding properties of porphyrin receptors, and some additional guests were selected to demonstrate a clear guest to cavitysize selection. The binding of $\mathrm{N}$-methylimidazole is commonly accepted as a model for oxygen binding capacities. See, e.g., ref 11.
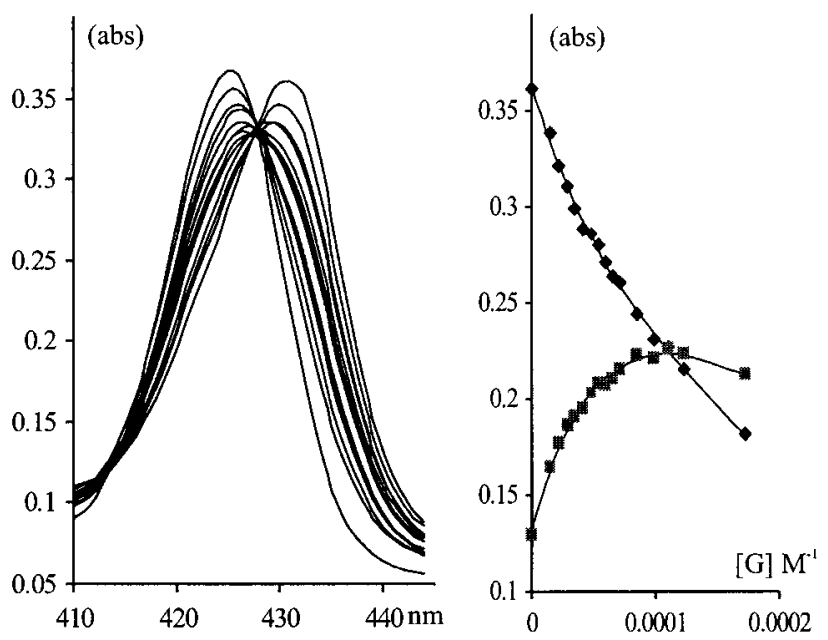

Figure 3. UV titration spectra showing the decrease of the Soret band of $\mathbf{1 7}$ and the increase of the Soret band of the complex upon picoline addition. The uncorrected data fit to a calculated curve for a 1:1 complexation with a stability constant of $2.3 \times 10^{5} \mathrm{M}^{-1}$.

Table 1. Binding Constants $\left(\times 10^{3} \mathrm{M}^{-1}\right)$ of the Complexation of N-Methylimidazole and Pyridine Guests by Cavitand Zn(II)-Porphyrins 17-20 Determined by UV Titration Experiments in $\mathrm{CHCl}_{3}$. The Experiments Were Carried Out in Duplicate with an Error Margin between 3 and $10 \%$

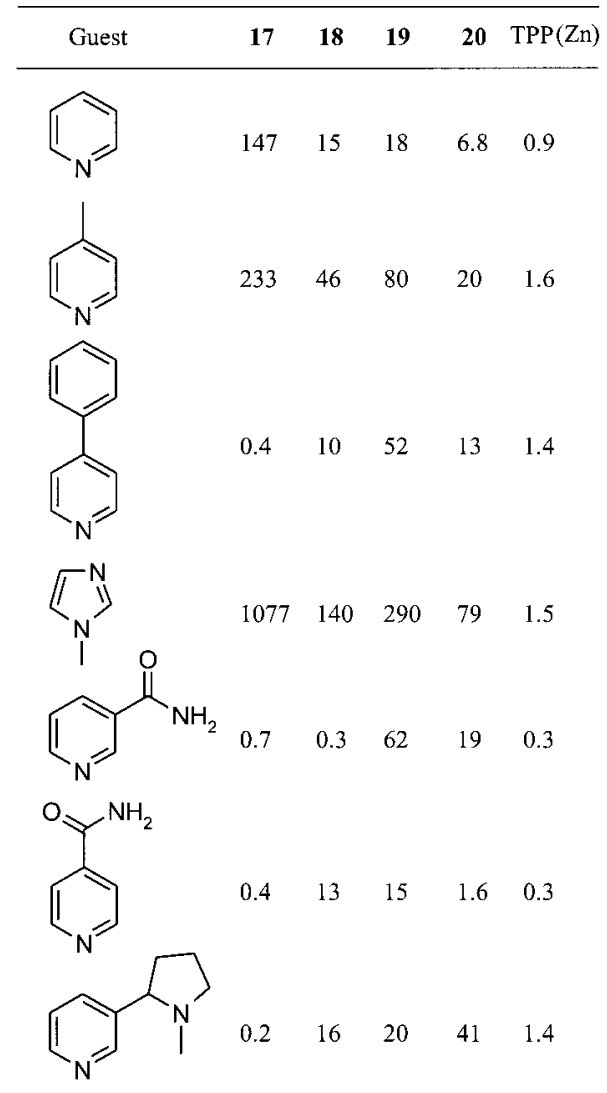

and pyridine guests was found for cavitand-capped $\mathrm{Zn}(\mathrm{II})$ - porphyrin 17, with the shortest distance between the cavitand and the porphyrin increasing the shielding effect. Furthermore, it has four spacers rigidifying the structure to a receptor having a defined cavity. A large difference between the smallest and the larger guests is observed. The larger guests (nicotin, nicotinamides, and p-phenylpyridine) bind at the outside of the receptor with 
a binding strength equal to or even lower ${ }^{26}$ than that to $\operatorname{TPP}(\mathrm{Zn})$. The binding of the smaller guests, N-methylimidazole, pyridine, and picoline, is strongly influenced by the capping effect of the cavitand, and they bind strongest following the trend of highest electron density on the donating nitrogen atom.

The longer and flexible spacers in $\mathbf{1 8}$ lead to a larger but less defined cavity, and most guests bind inside the receptor (except nicotin, not fitting in the cavity). The longer spacer reduces the capping effect of the cavitand, and the smaller guests bind typically weaker, although in the same order as 17. For the pyridines the cavitand capping effect is a factor ${ }^{27}$ of 6-32 (compared to TPP$(\mathrm{Zn})$ ), and the highest (94) value is that for $\mathrm{N}$-methylimidazole.

The cavitand-strapped porphyrin 19 lacks two spacers with respect to capped porphyrin 17. Consequently, the shielding effect on the porphyrin will be reduced and, more importantly, the flexibility of the system and the cavitand-porphyrin distance are slightly increased. This increase of distance allows p-phenylpyridine to be bound inside the receptor. The two new windows enable the sterically more demanding guests to bind inside. Strapped porphyrin 19 binds nicotinamide ${ }^{28}$ by a factor 200 times stronger (!) than that of $\operatorname{TPP}(\mathrm{Zn})$ and is the best of receptors 17-20 for binding nicotinamide, p-phenylpyridine, and isonicotinamide.

The elongation of the spacers in cavitand-strapped porphyrin $\mathbf{2 0}$ results in a diminished cavitand capping effect compared to 19. In $\mathbf{2 0}$ the flexibility of the spacers allows the molecule to fold its spacers toward the interior of the receptor, thereby minimizing its cavity size (vide supra). This folding process promotes the self-inclusion of a porphyrin phenyl moiety into the cavitand cavity. The axial binding of guests in $\mathrm{CHCl}_{3}$, in this case, has to compete with this process which is an additional energy barrier to overcome. In general, the overall binding affinities are less than those for 17-19, except for nicotin, which probably has a cooperative hydrogen-bond interaction with one of the spacer amides 29 enhancing the binding to receptor $\mathbf{2 0}$, ther eby becoming the best receptor for nicotin.

The binding of $\mathrm{N}$-methylimidazole by cavitand Zn(II )porphyrin $\mathbf{1 8}$ has been studied by ${ }^{1} \mathrm{H}$ NMR spectroscopy in $\mathrm{CDCl}_{3}$ to corroborate the result with the data obtained with UV spectroscopy (vide supra). Characteristic for the binding of $\mathrm{N}$-methylimidazole $\mathrm{e}^{30}\left(\mathrm{~K}_{\text {ass }}=1.4 \times 10^{5} \mathrm{M}^{-1}\right)$ are the very large shifts for the signals of the guest owing to the strong influence of the ring current of the porphyrin and its partial location in the cavity of the cavitand; the methyl group shifts from $\delta 3.6$ to -0.9 . Only small shifts are observed for signals originating from the hydrogen atoms at the porphyrin and the $\mathrm{OCH}_{2}$ moiety of the spacer.

\section{Conclusions}

Our results clearly demonstrate that a cavitand is an excellent cap for a porphyrin. The complexation depends

(26) One side of the porphyrin is blocked.

(27) The capping effect is expressed by comparison of the receptors binding affinity to that of $(\mathrm{Zn})$ TPP.

(28) On the basis of CPK molecular models, a cooperative hydrogen bond is possible between one of the amides of the spacers and the nicotinamide guest.

(29) Deviprasad, G. R.; D'Souza, F. Chem. Commun. 2000, 1915

(30) From the literature it is known that 2-methylimidazole typically binds stronger than $\mathrm{N}$-methylimidazole. See, e.g., ref 7. on the rigidity of the receptor, the number of spacers, and the distance between the porphyrin and the cavitand. Long flexible spacers result in a broader range of potential guests. In the case of $\mathbf{1 8}$ and $\mathbf{2 0}$, a moderate enhancement (10-90-fold) of the porphyrin binding properties is observed due to self-inclusion. Short, rigid spacers on the cavitand have a large impact on the binding properties. Strapped porphyrin 19 shows large binding enhancements for $\mathrm{N}$-methylimidazole, picoline, and nicotinamide (50-200-fold). The two additional rigid spacers in capped porphyrin 17 increase the capping effect to 700-fold in the case of $\mathrm{N}$-methylimidazole. Cavitand $\mathrm{Zn}(\mathrm{II})$ - porphyrin receptors 17 and $\mathbf{1 9}$ belong to the best receptors for $\mathrm{N}$-heterocycles reported to date.

\section{Experimental Section}

General. Melting points are uncorrected. Mass positive (FAB) spectra were obtained using m-nitrobenzyl alcohol as a matrix. Column chromatography was performed using silica gel 60 from Merck. All reactions were carried out under an argon atmosphere, and solvents, if necessary, were purified by standard procedures prior to use. The presence of solvents in the analytical samples was confirmed by ${ }^{1} \mathrm{H}$ NMR spectroscopy.

NMR. All ${ }^{1} \mathrm{H}(300 \mathrm{MHz})$ and ${ }^{13} \mathrm{C}$ NMR $(63 \mathrm{MHz})$ spectra were recorded in $\mathrm{CDCl}_{3}$ at ambient temperature $\left(30^{\circ} \mathrm{C}\right)$ unless stated otherwise. The chemical shifts are expressed relative to $\mathrm{CHCl}_{3}$ for ${ }^{1} \mathrm{H} \mathrm{NMR}$ (at $\delta 7.14$ ) and ${ }^{13} \mathrm{C} \mathrm{NMR} \mathrm{(at} \delta$ 78.4). NOESY, ${ }^{31}$ ROESY, 32 TOCSY (MLEV 17), 33 and COSY ${ }^{34}$ spectra were performed using standard Varian pulse programs. The TOCSY (MLEV 17) experiments were performed with mixing times of $30 \mathrm{~ms}$. The mixing times of the NOESY experiments ranged from 10 to $90 \mathrm{~ms}$. The mixing time of the ROESY experiments consisted of a spin-lock pulse of $2 \mathrm{kHz}$ field strength with a duration of $30 \mathrm{~ms}$, typically. All 2-D experiments were collected using 2-D hypercomplex data ${ }^{35}$ and Fourier transformed in the phase-sensitive mode after weighting with shifted square sine bells or shifted Gaussian functions. NMR data were processed by the standard VnmrS software packages on the Unity 400 WB host computers (SUN IPX and Sparc stations). Concentrations of the samples used were typically in the $5 \mathrm{mM}$ range. 6,18-Bis(aminomethyl)-12,24-(dimethyl)pentylcavitand ${ }^{14} \mathbf{1}, 6,12,18,24$-tetrakis(aminomethyl)pentylcavitand ${ }^{13} \mathbf{2}$, and 6,12,18,24-tetrakis(chloroacetamido- $\mathrm{N}$-methylene)pentyl cavitand ${ }^{13} \mathbf{5}$ were synthesized according to literature procedures reported by our group.

UV Titration Experiments and Binding Constant Determination. The concentrations of cavitand $\mathrm{Zn}(\mathrm{II})-$ porphyrins used for the determination of the binding constants by UV titrations were between 2 and $5 \mu \mathrm{M}$, and $\mathrm{N}$-methylimidazole and pyridine guests were added until more than $90 \%$ of complex formation was observed. Binding constants were determined by plotting the Soret absorbance band decrease of the free hosts against the guest concentration, and also by that of the Soret absorbance band increase of the complexes against the guest concentrations. The experimental data were fitted with the least-squares method to a theoretical curve calculated with a 1:1 binding model. The experiments were carried out in duplicate with an error margin between 3 and $10 \%$.

General Workup Procedures. Procedure A. The reaction was quenched with $\mathrm{HCl}(2 \mathrm{~N}, 100 \mathrm{~mL})$, followed by

(31) (a) J eener, J .; Meier, B. H.; Ernst, R. R. J . Chem Phys. 1979, 71, 4546. (b) Neuhaus, D.; Williamson, M. In The Nuclear Overhauser Effect in Structural and Conformational Analysis; VCH Publishers: Cambridge, 1989.

(32) Bothner-By, A. A.; Stephens, R. L.; Lee, L.; Warren, C. D.; J eanloz, R. W. J . Am. Chem. Soc. 1984, 106, 811.

(33) Bax, A.; Davis, D. J . Magn. Reson. 1985, 65, 355.

(34) Bax, A.; Freeman, R. J . Magn. Reson. 1981, 44, 542

(35) States, D. J .; Haberkorn, R. A.; Ruben, D. J. J. Magn. Reson. 1982, 48, 286 
washing the organic layer with water $(100 \mathrm{~mL})$ and $6 \mathrm{~N} \mathrm{NaOH}$ $(50 \mathrm{~mL})$, drying the organic layer over $\mathrm{MgSO}_{4}$, and evaporation of the solvent. Procedure $\mathbf{B}$. The solvent was removed in vacuo, and the residue was redissolved in $\mathrm{CH}_{2} \mathrm{Cl}_{2} / \mathrm{H}_{2} \mathrm{O}(200$ $\mathrm{mL} / 100 \mathrm{~mL}$ ). The organic layer was dried over $\mathrm{Na}_{2} \mathrm{SO}_{4}$ and concentrated to $10 \mathrm{~mL}$ (approximately), and the residue was separated by column chromatography $\left(\mathrm{SiO}_{2}, \mathrm{EtOAc}\right)$. Elution was performed with a gradient of $\mathrm{MeOH}(0,5,7,10 \%)$ in EtOAc. Procedure $\mathbf{C}$. The excess of pyrrole was removed in vacuo, and the residue was taken up in $\mathrm{CH}_{2} \mathrm{Cl}_{2} / 0.1 \mathrm{~N} \mathrm{NaOH}$ $\left(200 \mathrm{~mL} / 50 \mathrm{~mL}\right.$ ). The organic layer was dried over $\mathrm{Na}_{2} \mathrm{SO}_{4}$ and concentrated to $10 \mathrm{~mL}$ (approximately), and the residue was separated by column chromatography $\left(\mathrm{SiO}_{2}, \mathrm{CH}_{2} \mathrm{Cl}_{2}\right)$.

6,18-Bis(chloroacetamido- $\mathrm{N}$-methylene)-12,24-dimethylpentylcavitand (3). A solution of chloroacetyl chloride (1.05 g, $9.30 \mathrm{mmol})$ in $\mathrm{CH}_{2} \mathrm{Cl}_{2}(20 \mathrm{~mL})$ was added dropwise to a solution of 6,18-bis(aminomethyl)-12,24-(dimethyl)pentylcavitand $1(1.68 \mathrm{~g}, 1.86 \mathrm{mmol})$ in a mixture of $\mathrm{CH}_{2} \mathrm{Cl}_{2}(150 \mathrm{~mL})$ and $\mathrm{Et}_{3} \mathrm{~N}(15 \mathrm{~mL})$ at $-18{ }^{\circ} \mathrm{C}$, whereupon stirring was continued overnight at rt. Workup procedure A yielded $\mathbf{3}$ (1.92 g, 98\%) as a white solid, $\mathrm{mp} 100-102{ }^{\circ} \mathrm{C}:{ }^{1} \mathrm{H}$ NMR $\delta 0.92(\mathrm{t}, \mathrm{J}$ $=7.2 \mathrm{~Hz}, 12 \mathrm{H}), 1.30-1.50(\mathrm{~m}, 24 \mathrm{H}), 1.95(\mathrm{~s}, 6 \mathrm{H}), 2.10-2.30$ $(\mathrm{m}, 8 \mathrm{H}), 4.02(\mathrm{~s}, 4 \mathrm{H}), 4.34(\mathrm{~d}, \mathrm{~J}=6.9 \mathrm{~Hz}, 4 \mathrm{H}), 4.40(\mathrm{~d}, \mathrm{~J}=6.0$ $\mathrm{Hz}, 4 \mathrm{H}), 4.76(\mathrm{t}, \mathrm{J}=7.4 \mathrm{~Hz}, 4 \mathrm{H}), 5.94(\mathrm{~d}, \mathrm{~J}=6.9 \mathrm{~Hz}, 4 \mathrm{H})$, $6.96(\mathrm{~s}, 2 \mathrm{H}), 7.02(\mathrm{t}, \mathrm{J}=6.4 \mathrm{~Hz}, 2 \mathrm{H}), 7.11(\mathrm{~s}, 2 \mathrm{H}) ;{ }^{13} \mathrm{C} \mathrm{NMR} \delta$ $10.5,14.1,22.7,27.6,30.9,32.1,35.5,37.0,42.7,62.3,99.5$, $117.1,120.6,122.8,124.1,137.5,138.6,153.5,153.5,165.8$; FAB m/z 1055.5 [M + H] $]^{+}$, calcd 1055.5. Anal. Calcd for $\mathrm{C}_{60} \mathrm{H}_{76^{-}}$ $\mathrm{Cl}_{2} \mathrm{~N}_{2} \mathrm{O}_{10} \cdot 0.3 \mathrm{CH}_{2} \mathrm{Cl}_{2}: \mathrm{C}$, 66.96; $\mathrm{H}, 7.14 ; \mathrm{N}, 2.59$. Found: $\mathrm{C}$, $66.85 ; \mathrm{H}, 7.02 ; \mathrm{N}, 2.73$.

6,18-B is(5-bromopentylamido- $\mathrm{N}$-methylene)-12,24dimethylpentylcavitand (4). A solution of 6-bromohexanoyl chloride (1.99 g, $9.30 \mathrm{mmol})$ in $\mathrm{CH}_{2} \mathrm{Cl}_{2}(50 \mathrm{~mL})$ was added dropwise to a solution of 6,18-bis(aminomethyl)-12,24-(dimethyl)pentylcavitand $\mathbf{1}(1.68 \mathrm{~g}, 1.86 \mathrm{mmol})$ in a mixture of $\mathrm{CH}_{2} \mathrm{Cl}_{2}(150 \mathrm{~mL})$ and $\mathrm{Et}_{3} \mathrm{~N}(15 \mathrm{~mL})$ at $-10{ }^{\circ} \mathrm{C}$, whereupon stirring was continued for $2 \mathrm{~h}$ at $\mathrm{rt}$. Workup procedure $\mathrm{A}$ was followed by flash column chromatography $\left(\mathrm{SiO}_{2}, \mathrm{CH}_{2} \mathrm{Cl}_{2} / \mathrm{EtOAC}\right.$ $\left.7: 3, R_{f}=0.8\right)$, yielding $4(2.12 \mathrm{~g}, 91 \%)$ as a white solid, $\mathrm{mp}$ 143-145 ${ }^{\circ} \mathrm{C}$ : ${ }^{1} \mathrm{H}$ NMR $\delta 0.95(\mathrm{t}, \mathrm{J}=7.1 \mathrm{~Hz}, 12 \mathrm{H}), 1.25-1.45$ $(\mathrm{m}, 16 \mathrm{H}), 1.45-1.55(\mathrm{~m}, 4 \mathrm{H}), 1.55-2.00(\mathrm{~m}, 12 \mathrm{H}), 1.96(\mathrm{~s}, 6 \mathrm{H})$, $2.12-2.22(\mathrm{~m}, 4 \mathrm{H}), 2.29(\mathrm{t}, \mathrm{J}=6.8 \mathrm{~Hz}, 4 \mathrm{H}), 3.47(\mathrm{t}, \mathrm{J}=7.0$ $\mathrm{Hz}, 4 \mathrm{H}), 4.35(\mathrm{~d}, \mathrm{~J}=4.5 \mathrm{~Hz}, 4 \mathrm{H}), 4.37(\mathrm{~d}, \mathrm{~J}=7.2 \mathrm{~Hz}, 4 \mathrm{H})$, $4.74(\mathrm{t}, \mathrm{J}=7.7 \mathrm{~Hz}, 4 \mathrm{H}), 5.91(\mathrm{~d}, \mathrm{~J}=7.2 \mathrm{~Hz}, 4 \mathrm{H}), 6.23(\mathrm{t}, \mathrm{J}=$ $5.2 \mathrm{~Hz}, 2 \mathrm{H}), 6.96(\mathrm{~s}, 2 \mathrm{H}), 7.11(\mathrm{~s}, 2 \mathrm{H}) ;{ }^{13} \mathrm{C}$ NMR $\delta 10.5,14.2$, $22.7,23.5,24.2,26.1,27.4,27.6,30.2,32.3,36.3,44.7,60.3$, $99.3,117.2,120.1,123.5,123.9,137.5,138.5,153.4,153.6$, 172.7; FAB MS m/z 1255.5 [M + H ] $]^{+}$, calcd 1255.5. Anal. Calcd for $\mathrm{C}_{68} \mathrm{H}_{92} \mathrm{Br}_{2} \mathrm{~N}_{2} \mathrm{O}_{10} 0.3 \mathrm{Et}{ }_{3} \mathrm{~N}$ : C, 64.96; $\mathrm{H}, 7.38 ; \mathrm{N}, 2.23$. Found: $\mathrm{C}, 64.68 ; \mathrm{H}, 7.49 ; \mathrm{N}, 2.55$.

6,12,18,24-Tetrakis(5-bromopentylamido-N-methylene)pentylcavitand (6). A solution of 6-bromohexanoyl chloride $(5.60 \mathrm{~g}, 26.17 \mathrm{mmol})$ in $\mathrm{CH}_{2} \mathrm{Cl}_{2}(50 \mathrm{~mL})$ was added dropwise to a solution of $6,12,18,24$-tetrakis(aminomethyl)pentyl cavitand $2(2.77 \mathrm{~g}, 2.97 \mathrm{mmol})$ in a mixture of $\mathrm{CH}_{2} \mathrm{Cl}_{2}(100$ $\mathrm{mL})$ and $\mathrm{Et}_{3} \mathrm{~N}(10 \mathrm{~mL})$ at $0{ }^{\circ} \mathrm{C}$, whereupon stirring was continued overnight at $\mathrm{rt}$. Workup procedure $\mathbf{A}$ was followed by flash column chromatography $\left(\mathrm{SiO}_{2}, \mathrm{EtOAc} / \mathrm{MeOH} 4: 1, \mathrm{R}_{\mathrm{f}}=\right.$ 0.3). Addition of hexane to a $\mathrm{CH}_{2} \mathrm{Cl}_{2}$ solution yielded $\mathbf{4}$ (4.26 $\mathrm{g}, 88 \%)$ as a colorless oil: ${ }^{1} \mathrm{H}$ NMR $\delta 0.95(\mathrm{t}, \mathrm{J}=6.7 \mathrm{~Hz}$, $12 \mathrm{H}), 1.20-1.51(\mathrm{~m}, 32 \mathrm{H}), 1.51-1.69(\mathrm{~m}, 8 \mathrm{H}), 1.69-1.90(\mathrm{~m}$, $8 \mathrm{H}), 2.05-2.30(\mathrm{~m}, 16 \mathrm{H}), 3.52(\mathrm{t}, \mathrm{J}=6.2 \mathrm{~Hz}, 8 \mathrm{H}), 4.31(\mathrm{~d}$, $J=4.5 \mathrm{~Hz}, 4 \mathrm{H}), 4.38(\mathrm{~d}, J=6.5 \mathrm{~Hz}, 4 \mathrm{H}), 4.72(\mathrm{t}, \mathrm{J}=8.6 \mathrm{~Hz}$ $4 \mathrm{H}), 5.92(\mathrm{~d}, \mathrm{~J}=7.2 \mathrm{~Hz}, 4 \mathrm{H}), 5.93(\mathrm{t}, \mathrm{J}=5.2 \mathrm{~Hz}, 4 \mathrm{H}), 7.04(\mathrm{~s}$, $4 \mathrm{H}) ;{ }^{13} \mathrm{C}$ NMR $\delta 13.6,22.1,24.2,25.9,27.1,31.5,31.7,33.6$, 35.7, 36.4, 44.3, 52.7, 99.1, 119.3, 123.2, 137.6, 153.1, 172.0; FAB MS m/z $1637.5[\mathrm{M}+\mathrm{H}]^{+}$, calcd for $\mathrm{C}_{80} \mathrm{H}_{112} \mathrm{Br}_{4} \mathrm{~N}_{4} \mathrm{O}_{12}$ 1637.5 .

6,18-Bis[(2-formylphenoxy)acetamido- $\mathrm{N}$-methylene]12,24-dimethylpentylcavitand (7). A solution of salicylaldehyde $(1.39 \mathrm{~g}, 11.4 \mathrm{mmol})$ in $\mathrm{CH}_{3} \mathrm{CN}(10 \mathrm{~mL})$ was added to a suspension of $3(3.0 \mathrm{~g}, 2.84 \mathrm{mmol}), \mathrm{K}_{2} \mathrm{CO}_{3}(1.69 \mathrm{~g}, 12.2 \mathrm{mmol})$, and $\mathrm{Nal}$ (100 mg, catalyst) in $\mathrm{CH}_{3} \mathrm{CN}(100 \mathrm{~mL})$, whereupon the reaction mixture was refluxed overnight. Workup procedure $\mathrm{B}$ and column chromatography $\left(\mathrm{SiO}_{2}, \mathrm{EtOAc}, \mathrm{R}_{\mathrm{f}}=0.3\right)$ yiel ded 7 (2.91 g, 84\%) as a white solid, $\mathrm{mp} 215-217{ }^{\circ} \mathrm{C}:{ }^{1} \mathrm{H}$ NMR $\delta 0.91(\mathrm{t}, \jmath=6.9 \mathrm{~Hz}, 12 \mathrm{H}), 1.28-1.45(\mathrm{~m}, 24 \mathrm{H}), 1.91(\mathrm{~s}$, $6 \mathrm{H}), 2.13-2.27(\mathrm{~m}, 8 \mathrm{H}), 4.37(\mathrm{~d}, \mathrm{~J}=6.9 \mathrm{~Hz}, 4 \mathrm{H}), 4.50(\mathrm{~d}, \mathrm{~J}=$ $7.3 \mathrm{~Hz}, 4 \mathrm{H}), 4.53(\mathrm{~s}, 4 \mathrm{H}), 4.78(\mathrm{t}, \mathrm{J}=8.1 \mathrm{~Hz}, 4 \mathrm{H}), 5.98(\mathrm{~d}, \mathrm{~J}=$ $7.3 \mathrm{~Hz}, 4 \mathrm{H}), 6.90(\mathrm{~d}, \mathrm{~J}=8.4 \mathrm{~Hz}, 2 \mathrm{H}), 6.98(\mathrm{~s}, 2 \mathrm{H}), 7.12(\mathrm{~s}$, $2 \mathrm{H}), 7.18(\mathrm{t}, \mathrm{J}=7.5 \mathrm{~Hz}, 4 \mathrm{H}), 7.57(\mathrm{t}, \mathrm{J}=7.2 \mathrm{~Hz}, 2 \mathrm{H}), 7.78(\mathrm{~d}$, $\mathrm{J}=7.5 \mathrm{~Hz}, 2 \mathrm{H}), 7.83(\mathrm{t}, \mathrm{J}=5.7 \mathrm{~Hz}, 2 \mathrm{H}), 10.18(\mathrm{~s}, 2 \mathrm{H}) ;{ }^{13} \mathrm{C}$ NMR $\delta 9.9,13.6,20.3,27.1,29.6,31.5,33.3,36.4,59.8,67.7$, $99.0,112.6,116.5,119.8,121.6,122.8,123.4,124.5,133.4$ 135.5, 136.9, 137.9, 152.9, 153.2, 157.2, 166.8, 170.5, 189.6; $\mathrm{FAB} \mathrm{MS} \mathrm{m/z} \mathrm{1249.5} \mathrm{[M} \mathrm{+} \mathrm{H} \mathrm{+} \mathrm{Na]}]^{+}$, calcd 1249.6. Anal. Calcd for $\mathrm{C}_{74} \mathrm{H}_{86} \mathrm{~N}_{2} \mathrm{O}_{14} \cdot 0.3 \mathrm{CH}_{2} \mathrm{Cl}_{2}$ : C, 71.22; $\mathrm{H}, 6.97 ; \mathrm{N}, 2.24$. Found: C, 71.05; H, 6.89; N, 2.31.

6,18-Bis[5-(2-formylphenoxy)pentylamido-N-methylene]-12,24-dimethylpentylcavitand (8). A solution of salicylaldehyde ( $1.17 \mathrm{~g}, 10.4 \mathrm{mmol})$ in $\mathrm{CH}_{3} \mathrm{CN}(5 \mathrm{~mL})$ was added to a suspension of $\mathbf{4}(3.0 \mathrm{~g}, 2.84 \mathrm{mmol})$ and $\mathrm{K}_{2} \mathrm{CO}_{3}(1.69 \mathrm{~g}, 12.2$ $\mathrm{mmol})$ in $\mathrm{CH}_{3} \mathrm{CN}(50 \mathrm{~mL})$, whereupon the reaction mixture was refluxed overnight. Workup procedure $\mathrm{B}$ and column chromatography $\left(\mathrm{SiO}_{2}, \mathrm{CH}_{2} \mathrm{Cl}_{2} / \mathrm{E}\right.$ tOAc $\left.1: 1.1, \mathrm{R}_{\mathrm{f}}=0.1\right)$ yiel ded $8(2.91 \mathrm{~g}, 77 \%)$ as a white solid, $\mathrm{mp} 145-147^{\circ} \mathrm{C}$ : ${ }^{1} \mathrm{H}$ NMR $\delta$ $0.88(\mathrm{t}, \mathrm{J}=6.7 \mathrm{~Hz}, 12 \mathrm{H}), 1.25-1.44(\mathrm{~m}, 32 \mathrm{H}), 1.44-1.57(\mathrm{~m}$ $2 \mathrm{H}), 1.57-1.80(\mathrm{~m}, 2 \mathrm{H}), 1.80-1.91(\mathrm{~m}, 2 \mathrm{H}), 1.92(\mathrm{~s}, 6 \mathrm{H}), 2.10$ $2.25(\mathrm{~m}, 8 \mathrm{H}), 4.01-4.10(\mathrm{~m}, 8 \mathrm{H}), 4.20-4.32(\mathrm{~m}, 8 \mathrm{H}), 4.74(\mathrm{t}, \mathrm{J}$ $=8.1 \mathrm{~Hz}, 4 \mathrm{H}), 5.92(\mathrm{~d}, \mathrm{~J}=6.9 \mathrm{~Hz}, 4 \mathrm{H}), 6.15(\mathrm{t}, \mathrm{J}=8.1 \mathrm{~Hz}$, $4 \mathrm{H}), 6.90-7.10(\mathrm{~m}, 8 \mathrm{H}), 7.11(\mathrm{~s}, 2 \mathrm{H}), 7.46-7.53(\mathrm{~m}, 2 \mathrm{H}), 7.78-$ $7.81(\mathrm{~m}, 2 \mathrm{H}), 10.48(\mathrm{~s}, 2 \mathrm{H}) ;{ }^{13} \mathrm{C}$ NMR $\delta 9.8,13.5,19.7,22.1$, $24.1,24.6,25.2,25.9,27.1,27.8,27.9,28.0,28.3,29.5,31.5$ $31.7,32.6,33.7,35.2,35.9,36.5,44.2,59.8,67.6,76.8,98.7$, $112.0,116.7,119.7,120.0,123.1,123.5,124.3,127.7,135.5$, 137.0, 137.3, 138.0, 152.9, 153.0, 160.9, 162.0, 172.1, 189.2; FAB MS m/z 1339.8 [M + H] $]^{+}$, calcd 1339.7. Anal. Calcd for $\mathrm{C}_{82} \mathrm{H}_{102} \mathrm{~N}_{2} \mathrm{O}_{14} \cdot 0.8 \mathrm{CH}_{2} \mathrm{Cl}_{2}: \mathrm{C}, 70.65 ; \mathrm{H}, 7.42 ; \mathrm{N}, 1.99$. Found: $\mathrm{C}$, 70.35; H, 7.61; N, 2.29 .

6,12,18,24-Tetrakis[(2-formylphenoxy)acetamido- $\mathrm{N}$ methylene]pentylcavitand (9). A solution of salicylaldehyde $(2,40 \mathrm{~g}, 21.4 \mathrm{mmol})$ in $\mathrm{CH}_{3} \mathrm{CN}(5 \mathrm{~mL})$ was added to a suspension of $6,12,18,24$-tetrakis(chloroacetamidomethyl)pentylcavitand $\mathbf{5}(5.0 \mathrm{~g}, 3.96 \mathrm{mmol}), \mathrm{Nal}(0.1 \mathrm{~g}$, catalytic), and $\mathrm{K}_{2} \mathrm{CO}_{3}(5.0 \mathrm{~g}, \mathrm{mmol})$ in $\mathrm{CH}_{3} \mathrm{CN}(300 \mathrm{~mL})$, whereupon the reaction mixture was refluxed overnight. Workup procedure $\mathrm{B}$ and elution with a gradient of $\mathrm{EtOH}(0,10,33 \%)$ in EtOAC yiel ded $6(3.87 \mathrm{~g}, 61 \%)\left(33 \% \mathrm{EtOH}, \mathrm{R}_{\mathrm{f}}=0.3\right)$ as a red-brown oil: ${ }^{1} \mathrm{H} N M R \delta 0.91(\mathrm{t}, J=6.6 \mathrm{~Hz}, 12 \mathrm{H}), 1.05-1.70(\mathrm{~m}, 24 \mathrm{H})$, $2.00-2.40(\mathrm{~m}, 8 \mathrm{H}), 4.35(\mathrm{~d}, \mathrm{~J}=6.1 \mathrm{~Hz}, 4 \mathrm{H}), 4.36(\mathrm{~d}, \mathrm{~J}=7.4$ $\mathrm{Hz}, 4 \mathrm{H}), 4.51(\mathrm{~s}, 4 \mathrm{H}), 4.78(\mathrm{t}, \mathrm{J}=7.3 \mathrm{~Hz}, 4 \mathrm{H}), 6.01(\mathrm{~d}, \mathrm{~J}=7.4$ $\mathrm{Hz}, 4 \mathrm{H}), 6.90(\mathrm{~d}, \mathrm{~J}=8.0 \mathrm{~Hz}, 4 \mathrm{H}), 7.01(\mathrm{~s}, 4 \mathrm{H}), 7.14(\mathrm{t}, \mathrm{J}=4.8$ $\mathrm{Hz}, 4 \mathrm{H}), 7.44-7.55(\mathrm{~m}, 8 \mathrm{H}), 7.77(\mathrm{~d}, \mathrm{~J}=6.4 \mathrm{~Hz}, 4 \mathrm{H}), 10.08(\mathrm{~s}$, $4 \mathrm{H}) ;{ }^{13} \mathrm{C}$ NMR $\delta 14.0,22.5,27.4,30.0,31.9,33.6,36.8,42.4$, $67.5,99.7,113.0,119.8,121.9,123.2,124.9,133.0,135.9,138.1$, 153.5, 157.8, 167.1, 189.9; FAB MS m/z 1602.7 [M + H + Na $]^{+}$, calcd for $\mathrm{C}_{92} \mathrm{H}_{100} \mathrm{~N}_{4} \mathrm{NaO}_{20} 1602.8$.

6,12,18,24-Tetrakis[5-(2-formylphenoxy)pentylamido$\mathbf{N}$-methylene]pentylcavitand (10). A solution of salicylaldehyde (744 mg, $6.1 \mathrm{mmol}$ ) in $\mathrm{CH}_{3} \mathrm{CN}(5 \mathrm{~mL})$ was added to a suspension of $4(1.0 \mathrm{~g}, 0.61 \mathrm{mmol})$ and $\mathrm{K}_{2} \mathrm{CO}_{3}(1.69 \mathrm{~g}, 12.2$ $\mathrm{mmol})$ in $\mathrm{CH}_{3} \mathrm{CN}(50 \mathrm{~mL})$, whereupon the reaction mixture was refluxed overnight. Workup procedure $\mathrm{B}$ and elution with a gradient of $\mathrm{MeOH}(0,5,7,10 \%)$ in EtOAc yielded 6 (960 $\mathrm{mg}, 87 \%)\left(10 \% \mathrm{MeOH}, \mathrm{R}_{\mathrm{f}}=0.2\right)$ as a yellow-brown oil: ${ }^{1} \mathrm{H}$ NMR $\delta 0.93(\mathrm{t}\rfloor=,6.9 \mathrm{~Hz}, 12 \mathrm{H}), 1.20-1.50(\mathrm{~m}, 32 \mathrm{H}), 1.50$ $1.71(\mathrm{~m}, 8 \mathrm{H}), 1.71-1.91(\mathrm{~m}, 8 \mathrm{H}), 2.00-2.25(\mathrm{~m}, 16 \mathrm{H}), 4.09(\mathrm{t}$, $\mathrm{J}=4.8 \mathrm{~Hz}, 8 \mathrm{H}), 4.27(\mathrm{~d}, \mathrm{~J}=6.4 \mathrm{~Hz}, 4 \mathrm{H}), 4.38(\mathrm{~d}, \mathrm{~J}=7.5 \mathrm{~Hz}$, $4 \mathrm{H}), 4.75(\mathrm{t}, \mathrm{J}=8.1 \mathrm{~Hz}, 4 \mathrm{H}), 5.95(\mathrm{~d}, \mathrm{~J}=7.5 \mathrm{~Hz}, 4 \mathrm{H}), 5.94(\mathrm{t}$, $\mathrm{J}=5.1 \mathrm{~Hz}, 4 \mathrm{H}), 6.94-7.08(\mathrm{~m}, 8 \mathrm{H}), 7.09(\mathrm{~s}, 4 \mathrm{H}), 7.50-7.75$ $(\mathrm{m}, 4 \mathrm{H}), 7.82(\mathrm{~d}, \mathrm{~J}=7.2 \mathrm{~Hz}, 4 \mathrm{H}), 10.50(\mathrm{~s}, 4 \mathrm{H}) ;{ }^{13} \mathrm{C} \mathrm{NMR} \delta$ 13.6, 22.1, 24.6, 25.9, 27.1, 31.5, 31.7, 33.6, 35.8, 36.4, 44.3, $67.7,99.1,112.0,119.3,120.0,123.2,124.3,127.8,135.5,137.6$, 153.1, 160.9, 172.0, 189.5; FAB MS m/z 1806.2 [M + H] $]^{+}$, calcd 1805.9. Anal. Calcd for $\mathrm{C}_{108} \mathrm{H}_{132} \mathrm{~N}_{4} \mathrm{O}_{20} \cdot 1.7 \mathrm{CH}_{2} \mathrm{Cl}_{2}: \mathrm{C}, 67.55 ; \mathrm{H}$, 7.00; N, 2.87. Found: C, 67.33; $\mathrm{H}, 7.11 ; \mathrm{N}, 3.25$

6,18-Bis[(2-pyrrolylmethylphenoxy)acetamido-Nmethylene]-12,24-dimethylpentylcavitand (11). To a degassed solution of dialdehyde $7(150 \mathrm{mg}, 0.12 \mathrm{mmol})$ in pyrrole $(40 \mathrm{~mL})$ was added TFA (0.4 mL, catalytic). Stirring for 30 
min at rt, followed by workup procedure $\mathrm{C}$ and column chromatography $\left(\mathrm{SiO}_{2}, \mathrm{CH}_{2} \mathrm{Cl}_{2} /\right.$ EtOAc $\left.1: 1, \mathrm{R}_{\mathrm{f}}=0.2\right)$ yielded $\mathbf{1 1}(161 \mathrm{mg}, 90 \%)$ as a gray-blue heat- and light-sensitive solid, decomposing upon standing (!): ${ }^{1} \mathrm{H}$ NMR $\delta 0.94$ (t, J $=7.2$ $\mathrm{Hz}, 12 \mathrm{H}), 1.25-1.50(\mathrm{~m}, 24 \mathrm{H}), 1.82(\mathrm{~s}, 6 \mathrm{H}), 2.10-2.35(\mathrm{~m}, 8 \mathrm{H})$, $4.09(\mathrm{~d}, \mathrm{~J}=7.3 \mathrm{~Hz}, 4 \mathrm{H}), 4.20(\mathrm{~d}, \mathrm{~J}=5.1 \mathrm{~Hz}, 4 \mathrm{H}), 4.26(\mathrm{~s}, 4 \mathrm{H})$, $4.74(\mathrm{t}, \mathrm{J}=8.4 \mathrm{~Hz}, 4 \mathrm{H}), 5.55(\mathrm{brs}, 2 \mathrm{H}), 5.63(\mathrm{~d}, \mathrm{~J}=7.5 \mathrm{~Hz}$, $2 \mathrm{H}), 5.95-6.05(\mathrm{~m}, 6 \mathrm{H}), 6.65(\mathrm{~d}, \mathrm{~J}=8.1 \mathrm{~Hz}, 2 \mathrm{H}), 7.14(\mathrm{~s}, 2 \mathrm{H})$, $7.21(\mathrm{~s}, 2 \mathrm{H}), 7.21-7.25(\mathrm{~m}, 4 \mathrm{H}), 8.34$ (brs, $2 \mathrm{H}) ;{ }^{13} \mathrm{C} N M R$ $\left(\mathrm{CD}_{2} \mathrm{Cl}_{2}\right) \delta 9.0,13.3,13.4,22.1,27.1,29.7,31.5,32.9,36.6,38.2$, 59.7, 66.3, 98.4, 106.0, 107.5, 111.1, 116.4, 117.5, 119.8, 121.5, $122.3,123.3,127.8,128.9,130.4,130.6,137.4,137.6,152.9$, 153.1, 153.6, 166.8; FAB MS m/z $1458.7[\mathrm{M}+\mathrm{H}]^{+}$, calcd 1458.8. Anal. Calcd for $\mathrm{C}_{90} \mathrm{H}_{102} \mathrm{~N}_{6} \mathrm{O}_{12}: \mathrm{C}, 74.05 ; \mathrm{H}, 7.04 ; \mathrm{N}$, 5.76. Found: $\mathrm{C}, 74.32 ; \mathrm{H}, 6.92 ; \mathrm{N}, 5.67$.

6,18-Bis[5-(2-pyrrolylmethylphenoxy)pentylamido-Nmethylene]-12,24-dimethylpentylcavitand (12). To a degassed solution of dialdehyde $8(1.0 \mathrm{~g}, 0.75 \mathrm{mmol})$ in pyrrole (65 mL) was added TFA (0.1 mL, catalytic). Stirring for 30 min at rt followed by workup procedure $\mathrm{C}$ and column chromatography $\left(\mathrm{SiO}_{2}, \mathrm{CH}_{2} \mathrm{Cl}_{2} / \mathrm{EtOAc} 5: 2, \mathrm{R}_{\mathrm{f}}=0.3\right)$ yielded $12(620 \mathrm{mg}, 53 \%)$ as an off-white heat- and light-sensitive solid, decomposing upon standing (!): ${ }^{1} \mathrm{H} N \mathrm{NMR} \delta 0.91(\mathrm{t}$, J $=7.2$ $\mathrm{Hz}, 12 \mathrm{H}), 1.25-1.50(\mathrm{~m}, 32 \mathrm{H}), 1.52-1.75(\mathrm{~m}, 4 \mathrm{H}), 1.78(\mathrm{~s}, 6 \mathrm{H})$ $2.10-2.35(\mathrm{~m}, 12 \mathrm{H}), 3.93(\mathrm{t}, \mathrm{J}=6.3 \mathrm{~Hz}, 4 \mathrm{H}), 4.15-4.30(\mathrm{~m}$, $8 \mathrm{H}), 4.74(\mathrm{t}, \mathrm{J}=8.1 \mathrm{~Hz}, 4 \mathrm{H}), 5.80(\mathrm{~s}, 2 \mathrm{H}), 5.84(\mathrm{~d}, \mathrm{~J}=7.1 \mathrm{~Hz}$ $4 \mathrm{H}), 5.85$ (brs, 2H) $6.06-6.10(\mathrm{~m}, 2 \mathrm{H}), 6.61-6.64(\mathrm{~m}, 2 \mathrm{H})$, $6.83-6.90(\mathrm{~m}, 4 \mathrm{H}), 6.95(\mathrm{~s}, 2 \mathrm{H}), 7.06-7.10(\mathrm{~m}, 2 \mathrm{H}), 7.09(\mathrm{~s}$, $2 \mathrm{H}), 7.14-7.22(\mathrm{~m}, 2 \mathrm{H}), 8.46$ (brs, $2 \mathrm{H}) ;{ }^{13} \mathrm{C}$ NMR $\delta 14.1,14.2$, $22.7,25.1,25.6,27.6,28.8,30.1,32.1,32.2,34.2,36.3,36.8$ 37.0, 37.8, 67.8, 99.1, 106.5, 108.0, 112.0, 116.6, 117.2, 120.2, $120.8,123.5,124.1,127.9,129.5,131.3,132.9,137.6,138.6$, 153.4, 153.5, 156.0, 172.9; FAB MS m/z $1571.8[\mathrm{M}+\mathrm{H}]^{+}$, calcd 1571.9. Anal. Calcd for $\mathrm{C}_{98} \mathrm{H}_{118} \mathrm{~N}_{6} \mathrm{O}_{12}: \mathrm{C}, 74.88 ; \mathrm{H}, 7.57 ; \mathrm{N}$, 5.35. Found: C, 74.43; $\mathrm{H}, 7.42 ; \mathrm{N}, 5.57$.

General Procedure for the Insertion of $\mathbf{Z n ( I I ) . ~ T h e ~}$ reaction mixture of the cavitand $(2 \mathrm{H})$-porphyrin synthesis was evaporated to dryness and redissolved in $\mathrm{CH}_{2} \mathrm{Cl}_{2}(100 \mathrm{~mL})$ and aqueous $\mathrm{NaHCO}_{3}(50 \mathrm{~mL})$. The organic layer was dried over $\mathrm{Na}_{2} \mathrm{SO}_{4}$, and the residue was separated by column chromatography $\left(\mathrm{SiO}_{2}, \mathrm{CH}_{2} \mathrm{Cl}_{2} / \mathrm{Et}_{3} \mathrm{~N}, 99: 1\right)$. The strongly colored porphyrin bands of the cavitand $(2 \mathrm{H})$-porphyrins 13-16, containing non-porphyrin impurities, were isolated by elution with a gradient of $\mathrm{MeOH}$ (1 up to $10 \%$ ) in $\mathrm{CH}_{2} \mathrm{Cl}_{2} / \mathrm{Et}_{3} \mathrm{~N}$ (99:1) and evaporated to dryness. The residues were redissolved in $\mathrm{CHCl}_{3} / \mathrm{MeOH}(1: 1)$ and refluxed overnight with a large excess (approximately 50 equiv) of $\mathrm{Zn}(\mathrm{OAC})_{2}$. The reaction mixture was evaporated to dryness and redissol ved in $\mathrm{CH}_{2} \mathrm{Cl}_{2}(50 \mathrm{~mL})$ and $\mathrm{H}_{2} \mathrm{O}(2 \mathrm{~mL})$. The organic layer was dried over $\mathrm{Na}_{2} \mathrm{SO}_{4}$ and evaporated to dryness. This residue was redissolved in the eluent needed for column chromatography.

Cavitand-Capped Zn(II)-Porphyrin 17. A mixture of tetraal dehyde $\mathbf{9}(655 \mathrm{mg}, 0.41 \mathrm{mmol})$ and pyrrole $(111 \mathrm{mg}, 1.66$ $\mathrm{mmol})$ in propionic acid (200 mL) was refluxed overnight. F or the workup of $\mathbf{1 3}, 2 \% \mathrm{MeOH}$ was used in the eluent. The fraction with $R_{f}=0.4-0.7$ was again separated by column chromatography $\left(\mathrm{SiO}_{2}, \mathrm{Et}_{2} \mathrm{O} / \mathrm{CHCl}_{3} 2: 5\right)$. $\mathrm{Zn}(\mathrm{II})$ was inserted via the general procedure. Final purification by preparative $\mathrm{TLC}\left(\mathrm{SiO}_{2}, \mathrm{Et}_{2} \mathrm{O} / \mathrm{CHCl}_{3} 2: 5, \mathrm{R}_{\mathrm{f}}=0.15\right)$ gave $17(7.0 \mathrm{mg}, 0.9 \%)$ as a pinkish-purple solid, $\mathrm{mp} 209-211{ }^{\circ} \mathrm{C}$ (dec). Compound 13 consisting of at least two rotamers/isomers: ${ }^{1} \mathrm{H}$ NMR $\delta$ $-2.72(\mathrm{~s}, 1 \mathrm{H}),-2.80(\mathrm{~s}, 1 \mathrm{H})$. Compound 17: ${ }^{1} \mathrm{H}$ NMR (400 $\mathrm{MHz}) \delta 0.78(\mathrm{t}, \mathrm{J}=7.0 \mathrm{~Hz}, 6 \mathrm{H}), 0.93(\mathrm{t}, \mathrm{J}=7.0 \mathrm{~Hz}, 6 \mathrm{H})$, $1.05-1.50(\mathrm{~m}, 16 \mathrm{H}), 1.60-1.85(\mathrm{~m}, 8 \mathrm{H}), 3.29(\mathrm{~s}, 2 \mathrm{H}), 3.33(\mathrm{~s}$, $4 \mathrm{H}), 3.34(\mathrm{~s}, 2 \mathrm{H}), 3.50-3.80(\mathrm{~m}, 8 \mathrm{H}), 4.18(\mathrm{~d}, \mathrm{~J}=7.2 \mathrm{~Hz}, 4 \mathrm{H})$, 4.62-4.78 (m, 4H), 4.91 (brs, $1 \mathrm{H}), 5.16(\mathrm{~d}, \mathrm{~J}=7.2 \mathrm{~Hz}, 4 \mathrm{H})$, 5.90-5.98 (brs, $1 \mathrm{H}), 6.43(\mathrm{t}, \mathrm{J}=4.8 \mathrm{~Hz}, 1 \mathrm{H}), 6.51(\mathrm{brs}, 1 \mathrm{H})$, $7.02(\mathrm{~s}, 1 \mathrm{H}), 7.14-7.30(\mathrm{~m}, 7 \mathrm{H}), 7.40-7.76(\mathrm{~m}, 8 \mathrm{H}), 8.08(\mathrm{~d}, \mathrm{~J}$ $=8.0 \mathrm{~Hz}, 4 \mathrm{H}), 8.60-8.68(\mathrm{~m}, 8 \mathrm{H}) ;{ }^{13} \mathrm{C}$ NMR $\delta 12.8,16.9,26.1$, $28.9,31.5,33.2,30.1,32.1,32.2,33.8,35.5,40.5,47.9,67.8$, $99.1,104.6,104.9,118.0,121.4,122.4,123.6,120.8,124.0$, $124.6,128.1,129.6,130.6,134.4,134.7,134.9,138.3,141.8$, 142.0, 153.8, 153.9, 157.4, 163.0; FAB MS m/z 1836.0 [M + $\mathrm{H}]^{+}$, calcd 1836.5. Anal. Calcd for $\mathrm{C}_{108} \mathrm{H}_{104} \mathrm{~N}_{8} \mathrm{O}_{16} \mathrm{Zn}: \mathrm{C}, 70.67$; H, 5.71; N, 6.10. Found: C, 70.30; H, 6.02; N, 5.99.
Cavitand-Capped Zn(II)-Porphyrin 18. A solution of tetraaldehyde $\mathbf{1 0}$ (800 mg, $0.443 \mathrm{mmol}$ ) in freshly distilled $\mathrm{CH}_{2-}$ $\mathrm{Cl}_{2}\left(500 \mathrm{~mL}\right.$ ) was degassed at $-40{ }^{\circ} \mathrm{C}$ and, subsequently, saturated with argon. The solution was allowed to warm to rt, whereupon a solution of freshly distilled pyrrole (119 mg, $1.80 \mathrm{mmol})$ in $\mathrm{CH}_{2} \mathrm{Cl}_{2}(2 \mathrm{~mL})$ was added via a septum followed by the addition of a solution of freshly distilled $\mathrm{BF}_{3} \cdot \mathrm{OE}_{2}(252$ $\mathrm{mg}, 1.80 \mathrm{mmol})$ in $\mathrm{CH}_{2} \mathrm{Cl}_{2}(2 \mathrm{~mL})$. After the solution was stirred for $45 \mathrm{~min}$, p-chloroanil (500 mg, excess) was added, and the reaction mixture was refluxed for $1 \mathrm{~h}$. F or the workup procedure, $7 \% \mathrm{MeOH}$ in $\mathrm{CH}_{2} \mathrm{Cl}_{2}$ was used for column chromatography to obtain $(2 \mathrm{H})$-porphyrin 14. U pon the introduction of $\mathrm{Zn}(\mathrm{II})$ via the general procedure, the reaction mixture was separated by column chromatography $\left(\mathrm{SiO}_{2}, \mathrm{CH}_{2} \mathrm{Cl}_{2} / \mathrm{EtOAC}\right.$ $\left.1: 1, R_{f}=0.2\right)$, yielding $18(53 \mathrm{mg}, 6 \%$ ) as a purple solid, $\mathrm{mp}$ 208-210 ${ }^{\circ} \mathrm{C}$ (dec). Compound 14: ${ }^{1} \mathrm{H}$ NMR $\delta-2.88(\mathrm{~s}, 2 \mathrm{H})$. Compound 18: ${ }^{1} \mathrm{H}$ NMR $\left(400 \mathrm{MHz}, \mathrm{THF}^{\left.-\mathrm{d}_{8}\right)} \delta 0.60-0.63(\mathrm{~m}\right.$, $8 \mathrm{H}), 0.63-0.92(\mathrm{~m}, 40 \mathrm{H}), 1.09-1.60(\mathrm{~m}, 24 \mathrm{H}), 1.72-2.15(\mathrm{~m}$, $16 \mathrm{H}), 3.74(\mathrm{t}, \mathrm{J}=6.4 \mathrm{~Hz}, 8 \mathrm{H}), 3.90-3.95(\mathrm{~m}, 12 \mathrm{H}), 4.53(\mathrm{t}, \mathrm{J}$ $=8.4 \mathrm{~Hz}, 4 \mathrm{H}), 5.51(\mathrm{~d}, \mathrm{~J}=7.2 \mathrm{~Hz}, 4 \mathrm{H}), 6.71(\mathrm{t}, \mathrm{J}=6.0 \mathrm{~Hz}$, 4H), $6.97(\mathrm{~s}, 4 \mathrm{H}), 7.17-7.27(\mathrm{~m}, 8 \mathrm{H}), 7.56-7.70(\mathrm{~m}, 4 \mathrm{H}), 7.81-$ $7.88(\mathrm{~m}, 4 \mathrm{H}), 8.59(\mathrm{~s}, 8 \mathrm{H}) ;{ }^{13} \mathrm{C}$ NMR $\delta 16.8,26.0,28.8,31.1$, $32.8,33.1,33.9,35.4,37.2,38.4,40.4,72.9,76.2,104.3,116.4$, $119.5,122.6,128.6,132.4,134.1,137.0,139.3,141.4,153.7$, 157.6, 163.3, 174.6; FAB MS m/z $2058.3[\mathrm{M}+\mathrm{H}]^{+}$, calcd for $\mathrm{C}_{124} \mathrm{H}_{136} \mathrm{~N}_{8} \mathrm{O}_{16} \mathrm{Zn} 2057.9$.

Cavitand-Strapped Zn(II)-Porphyrin 19. A solution of dipyrromethane $\mathbf{1 1}(0.54 \mathrm{~g}, 0.37 \mathrm{mmol})$ and benzal dehyde (79 $\mathrm{mg}, 0.74 \mathrm{mmol})$ in freshly distilled $\mathrm{CH}_{2} \mathrm{Cl}_{2}(200 \mathrm{~mL})$ was degassed at $-40{ }^{\circ} \mathrm{C}$ and, subsequently, saturated with argon. The solution was allowed to warm to rt and TFA $(0.2 \mathrm{~mL}$, catalytic) was added, whereupon the reaction mixture was stirred for 45 min. Subsequently, p-chloroanil (500 mg, excess) was added and the reaction mixture was refluxed for $1 \mathrm{~h}$. For the workup procedure, $2 \% \mathrm{MeOH}$ in $\mathrm{CH}_{2} \mathrm{Cl}_{2}$ was used for column chromatography to obtain $(2 \mathrm{H})$-porphyrin 15 . $\mathrm{Zn}(\mathrm{II})$ was inserted via the general procedure and followed by column chromatography first using $\mathrm{CH}_{2} \mathrm{Cl}_{2}$ as the eluent to remove some impurities. Strapped porphyrin 19 (17 mg, 3\%) was isolated $\left(\mathrm{CH}_{2} \mathrm{Cl}_{2} / \mathrm{EtOAC} 1: 1, \mathrm{R}_{\mathrm{f}}=0.5\right)$ as a purple solid, $\mathrm{mp}$ 152-154 ${ }^{\circ} \mathrm{C}$ (dec). Compound 15: ${ }^{1} \mathrm{H}$ NMR $\delta-2.68$ (brs, $2 \mathrm{H}$ ). Compound 19: ${ }^{1} \mathrm{H}$ NMR $\left(400 \mathrm{MHz}_{1} \mathrm{CDCl}_{3} / \mathrm{THF}^{-\mathrm{d}_{8}}=1: 1\right) \delta$ $0.85-1.10(\mathrm{~m}, 12 \mathrm{H}), 1.10-1.80(\mathrm{~m}, 24 \mathrm{H}), 2.00(\mathrm{~s}, 3 \mathrm{H}), 2.03(\mathrm{~s}$, $3 \mathrm{H}), 2.12-2.16(\mathrm{~m}, 8 \mathrm{H}), 3.06(\mathrm{~d}, \mathrm{~J}=6.9 \mathrm{~Hz}, 4 \mathrm{H}), 3.55-3.95$ $(\mathrm{m}, 4 \mathrm{H}), 4.00-4.20(\mathrm{~m}, 4 \mathrm{H}), 4.72(\mathrm{~m}), 5.14(\mathrm{~d}, \mathrm{~J}=6.9 \mathrm{~Hz}, 4 \mathrm{H})$, 5.52-5.56 (brs, 1H), 5.93-5.97 (brs, $1 \mathrm{H}), 6.48(\mathrm{~s}, 2 \mathrm{H}), 6.75$ (s, $2 \mathrm{H}), 7.32-7.35(\mathrm{~m}, 4 \mathrm{H}), 7.40-7.50(\mathrm{~m}, 6 \mathrm{H}), 7.62(\mathrm{~d}, \mathrm{~J}=7.1$ $\mathrm{Hz}, 2 \mathrm{H}), 7.65(\mathrm{~d}, \mathrm{~J}=7.1 \mathrm{~Hz}, 2 \mathrm{H}), 7.68-7.80(\mathrm{~m}, 8 \mathrm{H}), 8.64-$ $8.90(\mathrm{~m}, 8 \mathrm{H}) ;{ }^{13} \mathrm{C}$ NMR $\delta 12.8,16.9,26.1,28.9,31.5,33.2,33.8$, $35.5,40.4,40.5,40.5,47.9,67.8,102.2,102.5,115.8,120.5$, $121.0,122.2,123.7,124.0,127.8,129.9,130.4,132.3,134.2$, $134.4,134.5,137.9,139.0,141.1,142.2,147.7,153.8,153.8$, $154.2,157.6,157.8,157.9,162.7,163.6,174.2 ; \mathrm{FAB} M S \mathrm{~m} / \mathrm{z}$ $1501.2[\mathrm{M}]^{-}$, calcd 1501.2. Anal. Calcd for $\mathrm{C}_{104} \mathrm{H}_{102} \mathrm{~N}_{6} \mathrm{O}_{12} \mathrm{Zn}$. 1.0THF-d $8:{ }^{36} \mathrm{C}, 73.14 ; \mathrm{H}, 5.80 ; \mathrm{N}, 4.74$. Found: C, 72.95; H, 5.64; N, 4.39

Cavitand-Strapped Zn(II)-Porphyrin 20. A sol ution of dipyrromethane 12 ( $0.81 \mathrm{~g}, 0.61 \mathrm{mmol}$ ) and benzal dehyde (128 $\mathrm{mg}, 1.22 \mathrm{mmol})$ in freshly distilled $\mathrm{CH}_{2} \mathrm{Cl}_{2}(200 \mathrm{~mL})$ was degassed at $-40{ }^{\circ} \mathrm{C}$ and, subsequently, saturated with argon. The solution was allowed to warm to rt and freshly distilled $\mathrm{BF}_{3} \cdot \mathrm{OEt}_{2}(0.1 \mathrm{~mL}$, catalytic) was added, whereupon the reaction mixture was stirred for $3 \mathrm{~h}$. Subsequently, p-chloroanil (500 mg, excess) was added and the reaction mixture was re fluxed for $1 \mathrm{~h}$. For the workup procedure, $2 \% \mathrm{MeOH}$ in $\mathrm{CH}_{2} \mathrm{Cl}_{2}$ was used for column chromatography to obtain (2H)-porphyrin 16. $\mathrm{Zn}(\mathrm{II})$ was inserted via the general procedure, and the reaction mixture was separated by column chromatography using $\left(\mathrm{CH}_{2} \mathrm{Cl}_{2} /\right.$ EtOAc $\left.1: 1, \mathrm{R}_{\mathrm{f}}=0.5\right)$ as the eluent. Strapped porphyrin $\mathbf{2 0}(55 \mathrm{mg}, 5 \%)$ was isolated as a purple solid, $\mathrm{mp}$ 159-161 ${ }^{\circ} \mathrm{C}$ (dec). Compound 16: ${ }^{1} \mathrm{H}$ NMR $\delta-2.68$ (brs, $2 \mathrm{H}$ ).

(36) The sample used for ${ }^{13} \mathrm{C}$ NMR was evaporated to dryness and used for elemental analysis. The cavity is probably occupied by a molecule of THF-d8. 
Compound 20: ${ }^{1} \mathrm{H}$ NMR (400 MHz, THF $\left.-\mathrm{d}_{8}\right) \delta 0.43-0.50(\mathrm{~m}$, $2 \mathrm{H}), 0.56-0.61(\mathrm{~m}, 2 \mathrm{H}), 0.76-0.82(\mathrm{~m}, 12 \mathrm{H}), 0.88(\mathrm{t}, \mathrm{J}=7.2$ $\mathrm{Hz}, 2 \mathrm{H}), 0.98(\mathrm{t}, \mathrm{J}=7.2 \mathrm{~Hz}, 2 \mathrm{H}), 1.04-1.16(\mathrm{~m}, 2 \mathrm{H}), 1.19-$ $1.40(\mathrm{~m}, 24 \mathrm{H}), 1.44-1.60(\mathrm{~m}, 4 \mathrm{H}), 1.75(\mathrm{~s}, 6 \mathrm{H}), 1.85-1.95(\mathrm{~m}$, $2 \mathrm{H}), 2.00-2.30(\mathrm{~m}, 8 \mathrm{H}), 3.37(\mathrm{t}, \mathrm{J}=6.8 \mathrm{~Hz}, 2 \mathrm{H}), 3.47(\mathrm{~d}, \mathrm{~J}=$ $7.2 \mathrm{~Hz}, 2 \mathrm{H}), 3.80(\mathrm{t}, \mathrm{J}=6.8 \mathrm{~Hz}, 2 \mathrm{H}), 3.88(\mathrm{~d}, \mathrm{~J}=7.2 \mathrm{~Hz}, 2 \mathrm{H})$, $4.07-4.09(\mathrm{~m}, 4 \mathrm{H}), 4.60(\mathrm{t}, \mathrm{J}=8.0 \mathrm{~Hz}, 2 \mathrm{H}), 4.68(\mathrm{t}, \mathrm{J}=8.0$ $\mathrm{Hz}, 2 \mathrm{H}), 5.37(\mathrm{~d}, \mathrm{~J}=7.2 \mathrm{~Hz}, 2 \mathrm{H}), 5.66(\mathrm{~d}, \mathrm{~J}=7.2 \mathrm{~Hz}, 2 \mathrm{H})$, 5.82 (brs, 1H), 6.50 (brs, 1H), $6.95(\mathrm{~s}, 2 \mathrm{H}), 7.02(\mathrm{~s}, 1 \mathrm{H}), 7.07$ $(\mathrm{s}, 1 \mathrm{H}), 7.18(\mathrm{t}, \mathrm{J}=7.6 \mathrm{~Hz}, 2 \mathrm{H}), 7.26(\mathrm{~d}, \mathrm{~J}=8.0 \mathrm{~Hz}, 2 \mathrm{H}), 7.37-$ $7.63(\mathrm{~m}, 12 \mathrm{H}), 7.84(\mathrm{~d}, \mathrm{~J}=7.6 \mathrm{~Hz}, 2 \mathrm{H}), 8.06(\mathrm{brs}, 4 \mathrm{H}), 8.65-$ $8.67(\mathrm{~m}, 4 \mathrm{H}) ;{ }^{13} \mathrm{C}$ NMR $\left(63 \mathrm{MHz}, \mathrm{THF}-\mathrm{d}_{8}\right) \delta 12.8,16.9,26.1$, 28.4, 30.1, 31.3, 32.1, 33.0, 33.1, 33.8, 35.5, 36.0, 36.1, 36.8,
$38.5,39.3,40.6,47.9,48.4,72.0,102.3,102.5,118.8,120.2$ $120.9,122.0,122.5,123.3,123.8,123.9,127.7,128.4,128.7$, $129.6,130.5,132.7,134.5,134.5,138.0,139.1,139.9,141.3$, 141.8, 147.5, 156.6, 157.0, 158.5, 174.2; FAB MS m/z 1825.8 $[\mathrm{M}+\mathrm{H}+\mathrm{Na}]^{+}$, calcd 1825.8. Anal. Calcd for $\mathrm{C}_{112} \mathrm{H}_{118} \mathrm{~N}_{6} \mathrm{O}_{12}-$ $\mathrm{Zn} \cdot 0.8 \mathrm{MeOH}$ : C, 73.99; H, $6.67 \mathrm{~N}, 4.59$. Found: C, 73.85; H, 6.37; N, 4.32

Acknowledgment. We are grateful to the Council for Chemi cal Sciences of The N etherlands Organization for Scientific Research (CW-NWO) for financial support.

J O010107K 